\title{
RECENT LITERATURE
}

\section{P.J. Mundy}

National University of Science and Technology, Bulawayo, Zimbabwe. mundy@gatorzw.com

http://dx.doi.org/10.4314/vulnew.v77i1.A

ALLAN, D. (2017). Power struggle. African Birdlife 5(5): 59.

Documents something of the electrocution and collisions suffered by vultures, particularly the Cape Griffon. Starts with the short note by Miles Markus in Nature in 1972!

ALLAN, D. (2017). Tawny tantrum. African Birdlife 5(6): 14-15.

An adult male attacks an adult Lappet-faced Vulture in mid-air, for no apparent reason. Good photos.

ALLAN, D. (2017). Back to the future. African Birdlife 5(6): 59.

Discusses the use of vultures in the 'traditional health industry' and in the 'fetish' trade. A perfect last sentence to this article.

ALLAN, D. (2017). Enigmatic giant. African Birdlife 6(1): 59.

Some accurate points about the Lappet-faced Vulture throughout its range.

ANON. (2016). Vulture circling. Birdwatch 289: 14.

Sightings of an immature Bearded Vulture in Gwent and Devon in the UK, in May! No bleached feathers. Is it the same one as seen in Belgium? Also noted in British Birds 109: 419-420.

ANON. (2016). Painkiller ban brings hope for India's vultures. Nature's Home (RSPB magazine) spring: 49.

In 2015, a record number of vultures were produced in captivity: 58, including nine Slender-billed Vultures.

ARRONDO, E., CORTÉS-AVIZANDA, A. \& DONÁZAR, J.A. (2015). Temporally unpredictable supplementary feeding may benefit endangered scavengers. Ibis 157: 648-651.

Small feeding stations, where the supply of food is temporally unpredictable, may counteract some negative effects from more intense feeding sites, particularly from domination by a large species, e.g. Eurasian Griffon. Aimed at the Egyptian Vulture in Northern Spain.

(email: Arrondo-bioeaf@gmail.com)

BAILlIE, E. \& MAASDORP, L. (2018). Another Egyptian Vulture in the Zambezi Valley. Honeyguide 64: 15.

A young immature was seen at carrion near to Chirundu, on 13 November 2018. Also a photograph is attached. 
BHUSAL, K.P., CHAPAGAIN, D., JOSHI, A.B., CHAUDHARY, I.P. \& CHAUDHARY, K. (July 2018). First release of captive White-rumped Vulture (Gyps bengalensis) into the wild in Nepal. [can't read the journal name!]

Six captive-bred birds were released in November 2017, in a vulture safe zone; all females. The site neighboured Chitwan National Park. The birds were tracked by satellite telemetry. This is the first VSZ in the world.

BILDSTEIN, K.L. (2017). Raptors: the curious nature of diurnal birds of prey. Cornell University Press, Ithaca. ISBN 9781501705793. \$35.

Nicely written, and in plain English, this is a survey of all raptors, about 332 species of them. Vultures get many mentions, particularly New World Vultures. Palm-nut Vultures are not included in the group. Calling them "obligate scavenging birds of prey", the author notes that 11 of 22 species (actually 12 in Table 8.1) are threatened, and are one of the most endangered groups of raptors.

(www.cornellpress.cornell-edu)

BOWDEN, C. (2018) Return of the vultures. RSPB Fellows’ News, Spring: 8-9.

The release of captive-bred vultures by Nepal, also wild birds with trackers, is being carefully watched by the Nepal Vulture Action Plan and SAVE.

BRINK, C.W., AMAR, A. \& THOMSON, R. (2018). On a plate. African Birdlife 6(2): 18.

An investigation into vulture restaurants and whether they are able to benefit vultures, or are there risks attached?

(email: fitz@uct.ac.za)

BROWN, C.J., BRIDGEFORD, P.A., BRAINE, S.G., PAXTON, M. \& VERSVELD, W. (2015). Breeding data on the birds of Namibia: laying months, colony and clutch sizes and egg measurements. Ornithological Observations 6: 92-196.

A quite superb compilation from 7231 nest record cards, and other sources. Altogether the authors analyse Egyptian Vulture (1 record), White-backed Vulture (872), Cape Vulture (69), Lappet-faced Vulture (1274) and White-headed Vulture (11), though 220 nest records are used in Figure 5. Earliest laying dates are at end-March for $\mathrm{WbV}$ and $\mathrm{LfV}$, and peaks in May and June respectively. Birds in Etosha laid one week earlier than those to the south.

(email: chrisbrown.namibia@gmail.com)

CAMIŇA, A. (2018). A correction to De Liberato et al. 2018 Neottialges (Caloenectes) vulturis (Dubinin, 1956) (Acari: Hypoderatidae) from the Eurasian griffon vulture (Gyps fulvus) in Italy. Acarologia 58: 987-988.

The bird may not have been born in Spain, and it might have been infested on any cliff used by vultures. (email: acamia@acrenasl.eu) 
CARNEIRO, C., MONTEIRO, H., HENRIQUES, M. et al. (2017). Birds of João Vieira and Poilão Marine National Park, Bijagós, Guinea-Bissau, including first country records of four species. Bulletin African Bird Club 24: 182-191.

These are the four southern-most islands off the country. The Palm-nut Vulture occurs on all of them, up to 30 birds per sq.km; egg-laying starts in November. Only one Hooded Vulture was ever seen in the area, though it is "common" in the archipelago as a whole.

(email: camilofcarneiro@gmail.com)

CAUCANAS, G., PIOT, B., BARLOW, C.R. \& PHIPPS, W.L. (2018). A major count of the Egyptian Vulture Neophron percnopterus in Senegal in November 2017, with notes on its history and current status in Senegal and The Gambia. Malimbus 40: 55-66.

A group of 30 was seen in the Boundon Community Nature Reserve in east Senegal, being 10 adults and 20 immatures, drinking at the Falemé River. GPS locations of three adults are also shown, tagged in the Iberian peninsula. A poisoning incident in the NR is documented from December 2015.

(email: gabriel.caucanas@gmail.com)

CHIWESHE, N. (2015). Status of the Cape Griffon at Wabai Hills, Zimbabwe. Diamond Route Newsletter [South Africa] June: 10.

In August 2014, none was seen on the rock, though it was present at the restaurant, and roosting (perhaps) in trees.

DABONE, C., OUEDA. A., ADJAKPA, J.B., BUIJ, R., OUEDRAOGO, I., GUENDA, W. \& WEESIE, P.D.M. (2016). Phénologie de la reproduction de Vautour charognard Necrosyrtes monachus en zone soudano-sahélienne (Garango, Burkina Faso), 2013-2015. Malimbus 38: 38-49.

Twenty nests were followed in the first year, and 56 in the second. Copulations, nest construction, clutches (all of one egg), incubation (44-50 days), nestling period (101-121 days), and fledging were observed.

(email: dapexi@yahoo.fr)

DABONE, C., BUIJ, R., OUEDA, A., ADJAKPA, J.B., GUENDA, W. \& WEESIE, P.D.M. (2019). Impact of human activities on the reproduction of Hooded Vultures Necrosyrtes monachus in Burkina Faso. Ostrich 90: 53-61.

Studied in the south-east over two years, 2013-2015, involving 20 and 56 nests respectively. Productivity was about 0.57 fledglings per pair. Success increased with closer distance to human settlements. (email: dabepxi@yahoo.fr) 
DEMEY, R. (ed.)(2016). Recent reports. Bulletin African Bird Club 23: 104-123.

A few Egyptian Vultures were sighted in Kenya, and a Palm-nut Vulture in the Nairobi National Park. On 28 October 2015, two Rüppell's Griffons and 3500 Eurasian Griffons crossed the Strait and passed Jebel Moussa in Morocco; four Rüppell's Griffons were also seen in June. Two nests of Egyptian Vultures were found in eastern Niger. A Rüppell's Griffon was caught on camera in the Blouberg Nature Reserve, South Africa; thought to be breeding with a Cape Griffon; for several weeks an adult Palm-nut Vulture was seen at Swellendam. In Zimbabwe, a Palm-nut Vulture was seen in the south-east corner.

(email: rondemeyl@gmail.com)

DEMEY, R. (ed.)(2016). Recent reports. Bulletin African Bird Club 23: 231-249.

A "pair" of Egyptian Vultures was sighted in Tsavo East National Park. Four Rüppell's Griffons were seen at Jebel Moussa, Morocco, on 5 May, and on 7 May there was a group of 58 Egyptian Vultures, six Rüppell's and >800 Eurasian Griffons, and surprisingly, three Cinereous Vultures, at the same place. Several Palm-nut Vultures were seen singly in South Africa, and an adult Egyptian Vulture in the Kruger National Park on 14 February 2016.

(email:rondemeyl@gmail.com)

DEMEY, R. (ed.)(2017). Recent reports. Bulletin African Bird Club 24: 98-123.

Palm-nut Vultures recorded in the Pendjari and W National Parks (Benin); ten Lappet-faced Vultures in Mabuasehube (Botswana); 62 pairs (= occupied territories) of the Egyptian Vulture subsp. majorensis and a total of 277 individuals were counted in the Canary Islands in 2015, most on Fuerteventura; an immature White-headed Vulture at Comoé N.P. and three White-backed Vultures over Lamto (Ivory Cost); Egyptian Vultures were seen in several places in Kenya; one Rüppell's Griffon was in a flock of Eurasian Griffons south of Jbel Moussa, opposite Gibraltar, in July (Morocco); several Palm-nut Vultures were seen in South Africa, at Bethlehem, and Limpopo, North West, KwaZulu-Natal and Western Cape provinces, Hooded Vultures in KwaZulu-Natal, a juvenile White-backed Vulture south of Eland's Bay (Atlantic coast) and inland to Clanwilliam, and another juvenile in Gauteng, and a Rüppell's Griffon at the Cape Griffon Colony at Blouberg; a Palm-nut Vulture and Egyptian Vultures in Zimbabwe, and four species on a carcass just north of Bulawayo.

(email address: rondemey1@gmail.com)

DEMEY, R. (ed.)(2017) Recent reports. Bulletin African Bird Club 24: 229-252.

A White-headed Vulture was seen in central Angola; several White-backed Vultures on nests in Borassus palms in northern Benin (Pendjari); one adult White-backed Vulture in the south-east corner of Egypt (first for the country) with 19 Lappet-faced Vultures; one Rüppell's Griffon near 
Dakhla in the Atlantic Sahara of Western Sahara (wrongly called Morocco here); an immature Egyptian Vulture in the Kruger N.P. of South Africa and an adult nearby over Hoedspruit, single White-backed Vultures in the Western and Eastern Cape, and four sightings of Lappet-faced Vultures in northern South Africa; a Lappet-faced Vulture (photographed) with several Whitebacked Vultures at Nyamlell in South Sudan; and an adult Egyptian Vulture in the Hwange N.P. of Zimbabwe.

(email: rondemey1@gmail.com)

DEMEY, R. (ed.)(2018). Recent reports. Bulletin African Bird Club 25: 88-108.

A "pair" of White-headed Vultures was seen in the Ouadi Rimé-Ouadi Achim Game Reserve in Chad in late 2017. A Palm-nut Vulture was in Nairobi NP in July, and another in the Mara Triangle in November. A juvenile Cinereous Vulture was photographed in Banc d'Arguin NP (Mauritania) in December - first record for the country. A Rüppell's Griffon was photographed near Dakhla in Western Sahara in June, at least the second sighting for the country, the first being three birds near Aousserd in August 2011. At Jbel Moussa in Morocco, a White-backed Vulture (second for the country, the first being near Tétouan in May 2014) was seen with Rüppell's and Eurasian Griffons in July. In November, four Cinereous and 2700 Eurasian Griffons were at Tangier having crossed the Strait of Gibraltar. A juvenile Rüppell's Griffon was caught on a camera trap at Gorongosa NP in November (Mozambique) - first record for the country. An immature Egyptian Vulture was in the west of Etosha NP (Namibia) in November. Another was seen near Saint-Louis (Senegal) on Christmas Day, and a count of 32 was made at Boundon Community NR in November. An immature Egyptian Vulture was seen many times in the Kruger NP (South Africa) in the second half of 2017. A White-backed Vulture was in the Western and Eastern Cape, and two were near Port Elizabeth in August. A Hooded Vulture was seen near Hermanus in December. In Zambia a survey in the Kafue Flats in August located 49 White-backed Vultures nests and a Lappet-faced Vulture nest.

(email: rondemey1@gmail.com

DEMEY, R. (ed.)(2018). Recent reports. Bulletin African Bird Club 25: 230-251.

Near the Oryx camp in Chad, a breeding Lappet-faced Vulture was seen in April 2018; about 12 Rüppell's Griffons on cliffs near Aboudeia. A Cinereous Vulture was videoed in February and March in The Gambia - the first record for the country. Immature Palm-nut Vultures were in Nairobi NP and Lake Nakuru, early 2018. An immature Egyptian Vulture was near Windhoek in January. Senegal had two sightings of immature Cinereous Vultures in early 2018, and an Egyptian Vulture in December 2017. An immature Egyptian Vulture in Kruger, a Hooded Vulture in the Western Cape, and three Palm-nut Vultures (incl. an adult at Polokwane), all in South Africa in first half of 2018.

(email: rondemey1@gmail.com) 
FINKELSTEIN, M.E., BRANDT, J., SANDHAUS, E., GRANTHAM, J., MEE, A., SCHUPPERT, P.J. \& SMITH, D.R. (2015). Lead exposure risk from trash ingestion by the Endangered California Condor (Gymnogyps californianus). Journal Wildlife Diseases 51: 901-906.

Trash items were collected from condor nest areas and nestlings in California, 2002-2008, 1413 items in total. Only 27 items had lead above a threshold, of which 22 were ammunition. In general, non-ammunition trash (glass, plastic, etc.) does not pose a lead exposure.

(email-myraf@gmail.com)

GBOGBO, F., ROBERTS, J. S. T. \& AWOTWE-PRATT, V. (2016). Some important observations on the populations of Hooded Vultures Necrosyrtes monachus in urban Ghana. International Journal of Zoology vol. 2016, 6 pages.

In 2012, 257 vultures were counted at roosts in the entire Accra metropolitan area, with a human population of about four million. Use of vultures in "black magic" and for human consumption is reported. Competition from Pied Crows is proposed, along with other factors, as the vulture numbers have probably declined.

(email: fgbogbo@ug.edu.gh)

HARVEY, S. (2016). Vulture culture. BBC Wildlife 34(10): 38-43.

The editor of the magazine travelled to Monfragüe National Park in Extremadura. Eurasian Griffons and Cinereous Vultures were in abundance, and a couple of Egyptian Vultures were also seen. She notes that wind farms and the introduction of diclofenac are problems.

HOLLAND, A.E., BYRNE, M.E., BRYAN, A.L., DEVAULT, T.L., RHODES, O.E. \& BEASLEY, J.C. (2017). Fine-scale assessment of home ranges and activity patterns for resident black vultures (Coragyps atratus) and turkey vultures (Cathartes aura). PLoS ONE 12(7): e 0179819.

For 18 vultures (nine of each) for just over two years, no less than 2.8 million locations were collected by GSM/GPS transmitters. Mean monthly home ranges for turkey vultures $\left(61 \mathrm{~km}^{2}\right)$ were $50 \%$ larger than for black vultures. Also turkey vultures spent more time in flight (56\% vs. $37 \%$ ). Mean core area sizes did not differ (av. $\left.0.43 \mathrm{~km}^{2}\right)$.

HURRELL, S. (2016). Two steps towards death one towards life. BirdLife The Magazine 38(2): 1823.

A brief review of the situation for Africa's vultures, with 7 of 11 "on the edge of extinction". Introduces Ms Masumi Gudka as BirdLife's new vulture conservation manager, based in Nairobi, and also the Love Vultures campaign. Graced by a lovely if blurry photo of an adult White-headed Vulture.

HURRELL, S. (2017). We need to talk about vultures. BirdLife The Magazine 39(3): 21-25.

An update on what's happening in Asia, Europe, Africa, and internationally. Supports the MsAP (Bonn Convention). (email: birdlife@ birdlife.org) 
ISHTIAQ, F., PRAKASH, V., GREEN, R.E. \& JOHNSON, J. (2015). Management implications of genetic studies for ex situ populations of three critically endangered Asian Gyps vultures. Animal Conservation 18: 259-270.

Microsatellite markers were used to examine genetic diversity and relatedness among individuals caught for the captive breeding programmes. Inbreeding coefficients were low, and the great majority were unrelated.

(email: ishtiaq.farah@gmail.com)

JALLOW, M., BARLOW, C. R., SANYANG, L., DIBBA, L., KENDALL, C., BECHARD, M. \& BILDSTEIN, K.L. (2016). High population density of the Critically Endangered Hooded Vulture Necrosyrtes monachus in Western Region, The Gambia, confirmed by road surveys in 2013 and 2015. Malimbus 38: 23-28.

Along $129 \mathrm{~km}$ of mainly tar roads, 1543 vultures were sighted in September/October 2013, and along $195 \mathrm{~km}$ in July 2015 no less than 3416 were sighted. Numbers along route 2 (about 50km long) peaked at about 26 per $\mathrm{km}$. Given an overall survey area of $600 \mathrm{~km}^{2}$, the authors propose a population of 10500 Hooded Vultures! - of "global significance".

(email: bildstein@hawkmtn.org)

JOHNSON, T.F. \& MURN, C. (2019). Interactions between Pied crows Corvus albus and breeding White-backed vultures Gyps africanus. Ethology Ecology and Evolution 31: 240-248.

Dummy eggs and camera traps were used at vulture nests near to Kimberley. From 47 egg predation events, 37 were attributed to the crows. Crows also mobbed the incubating vultures.

(email: campbell@hawkconservancy.org)

KANE, A., WOLTER, K., NESER, W., KOTZE, A., NAIDOO, V. \& MONADJEM, A. (2016). Home range and habitat selection of Cape Vultures Gyps coprotheres in relation to supplementary feeding. Bird Study 63: 387-394.

From 28 Cape Griffons (15 adult and 13 immature) that were tracked by GPS-GSM. Immatures had much larger home ranges than adults, and adults in the wet season (non-breeding) had larger ranges than in the dry season. Birds had more of an association with a colony than with a restaurant.

(email: adam.kane@ucc.ie)

KENDALL, C. (2018). Off \& away. Vulture's journey of a lifetime. African Birdlife 6(5): 12-13.

An immature White-backed Vulture was tagged in southern Tanzania in October 2016. It flew more than $2000 \mathrm{~km}$ to South Africa through eight countries! A map is provided.

KLEIN, K. (2016). California Condor population reaches new heights in 2015. Yale Environment 360, 15 June: $1-2$.

The total number of condors in the wild in 2015 was 270. More chicks are surviving, and the birds are becoming increasingly independent and expanding their range. No electrocution since 2004. Lead poisoning remains a problem. 
LANG, D. \& GALLEGOS, L. (2015). Vulture verses: love poems for the unloved. Prospect Park Books, Altadena (CA). 32pp. ISBN 978-1-938849-64-0.

Includes one short poem to the Turkey Vulture - "please be mine". The $1^{\text {st }}$ author dedicates the book to her four favourite turkey vultures. Lauren is the artist.

(www.prospectparkbooks.com)

LAW, J. (2018). Saving the sentinels of the sky. BirdLife The Magazine 40(4): 36-38.

With many photographs, a short piece on a new initiative in Kenya's Masai Mara - a rapid-response unit of park rangers to combat vulture poisonings.

LONG, S. (2017). An Egyptian Vulture in Hwange National Park. Honeyguide 63: 71-72.

An immature was seen, and photographed, at Shumba Pan in November 2016. It was frequently seen up to end-January 2017.

(email: stephen@bhejanetrust.org)

LOWE, G.D. (2016). Can some African vultures locate carrion by its smell? Honeyguide 62: 139140.

A circumstantial observation in April 2016 that these four or five vultures (species unidentified, but perhaps Hooded Vultures) could have detected a very smelly lion carcass kept in a cold room.

(email: wildfire@mweb.co.zw)

MAASDORP, L. (2016). Report on vulture feeding at Rifa Conservation Camp, 1989-2015. Honeyguide 62: 157-165.

A stunning effort over 26 years of putting out carcasses and counting the vultures (and other birds and animals) that attended. One hundred counts were made, totalling 6692 vultures, of which $81.8 \%$ were White-backed Vultures, 12.7\% Hooded Vultures, 2.8\% Lappet-faced Vultures, 2.6\% Whiteheaded Vultures, and three Cape Griffons. Generally the Hooded Vulture was the first to see the carcasses, land, and feed on it.

(email: piumosso@zol.co.zw)

MARSHALL, B. (2017). The status of the Egyptian Vulture in Zimbabwe. Honeyguide 63: 72-73.

Ten sightings since 1980, of all age classes. Is it breeding near the Zambezi River?

(email: brian.marshall01@gmail.com)

MONADJEM, A., WOLTER, K., NESER, W. \& BILDSTEIN, K. (2016). Hooded Vulture Necrosyrtes monachus and African White-backed Vulture Gyps africanus nesting at the Olifants River Private Nature Reserve, Limpopo province, South Africa. Ostrich 87: 113-117.

Twelve nests (= pairs) of the first and 24 nests of the second were found on or near the Olifants River riverine. Most Hooded Vulture nests were in the Ebony tree, whereas most White-backed 
Vultures nested in the Sycamore Fig. Inter-nest distances and breeding success of Hooded Vultures are also given.

(email: ara@uniswa.sz)

MURN, C., BOTHA, A. \& WILSON, B. (2017). The changing sizes of critically endangered Whitebacked Vulture breeding colonies around Kimberley, South Africa. African Journal of Wildlife Research 47: 144-148.

Surveys by helicopter over six colonies were flown in July 2014. From the counted nests plus a correction factor, the estimate of 177 nests had decreased from 240 in 2001, by 26\%. Two colonies had increased (Dronfield and Secretarius), whereas Paardeburg collapsed to zero.

(email: campbell@hawkconservancy.org)

MURN, C., MUNDY, P., VIRANI, M.Z., BORELLO, W.D., HOLLOWAY, G.J. \& THIOLLAY, J.-M. (2016). Using Africa's protected area network to estimate the global population of a threatened and declining species: a case study of the Critically Endangered White-headed Vulture Trigonoceps occipitalis. Ecology and Evolution 6(4): 1092-1103.

Across a fragmented range, 400 protected areas were estimated to host 1893 nests. The total population of the species was estimated at about 5484 birds.

(email: campbell@hawkconservancy.org)

NEWTON, I. (2016). The plight of the world's vultures. British Birds 109: 424-428.

A good summary of the situation to date in Asia and Europe, not quite so good for Africa. Includes two photographs, each with dozens of vultures. The BirdLife Partnership has produced a ten-year plan, and British Birds has given a conservation grant towards that.

OGADA, D., BOTHA, A. \& SHAW, P. (2016). Ivory poachers and poison: drivers of Africa's declining vulture populations. Oryx 50: 593-596.

From 11 poaching incidents in seven countries, 155 elephants and 2044 vultures were killed by poison. One incident in Zimbabwe killed 135 elephants- but only 219 vultures!

(email: ogada.darcy@peregrinefund.org)

OPPEL, S., DOBREV, V., ARKUMAREV, V., SARAVIA, V., BOUNAS, A., KRET, E., VELEVSKI, M., STOYCHEV, S. \& NIKOLOV, S.C. (2015). High juvenile mortality during migration in a declining population of a long-distance migratory raptor. Ibis 157: 545-557.

Nineteen nestlings were fitted with satellite transmitters in Bulgaria, Greece, FYRM and Albania, in 2010-2014. Those who flew across the Mediterranean sea died, those who flew into Turkey then thru the Levant survived. Survival in first year was $30 \%$.

(email: steffen.oppel@rspb.org.uk) 
OUOBA, F., TANKOANO, T., SAGNA, A.G. \& BROUWER, J. (2016). An ethno-ornithological contribution: four traditional bird stories from the Gourmantché. Malimbus 38: 29-32.

Includes "How the Hooded Vulture... lost the feathers on its head". But the vulture fell in love with the king's/chief's favourite, was discovered, and had his head and neck feathers taken off.

(email:-brouwereac@online.nl)

PARRY, R.L. (2016). Even vultures go hungry in North Korea. The Times [newspaper] 26 March, p. 47.

The [South] Korea Institute of Environmental Ecology has been tracking migratory Cinereous Vultures since 2011. The birds were "not alighting at all" as they flew for $320 \mathrm{~km}$ over North Korea. There are "barely" any animal carcasses to be found!

(With thanks to Clive Slater for sending me this gem).

PFEIFFER, M.B., VENTER, J.A. \& DOWNS, C.T. (2015). Foraging range and habitat use by Cape Vulture Gyps coprotheres from the Msikaba colony, Eastern Cape province, South Africa. Koedoe 57: a1240.

MCPs for adult birds $(\mathrm{n}=5)$ in the breeding season averaged $14707 \mathrm{~km}^{2}$ and in the non-breeding season $(\mathrm{n}=4) 16887 \mathrm{~km}^{2}$. Commercial farmland was not preferred, in spite of all the vulture restaurants, whereas subsistence farmland and woody vegetation were.

(email: downs@ukzn.ac.za)

PFEIFFER, M. B., VENTER, J.A. \& DOWNS, C.T. (2017). Observations of microtrash ingestion in Cape Vultures in the Eastern Cape, South Africa. African Zoology 52: 65-67.

Nine nestlings were examined at the Colleywobbles colony in 2015. Two regurgitated a few items of plastic and glass.

(email: Downs@ukzn.ac.za)

POMEROY, D., KIBUUlE, M., NALWANGA, D., KAPHU, G., OPIGE, M. \& SHAW, P. (2019). Densities and population sizes of raptors in Uganda's conservation areas. Ostrich 90: 25-36.

Six species of vultures were included by driving road transects. White-backed Vultures were estimated at 10-22 birds per 100 sq. km, but White-headed Vultures at only 0.5-2, with the latter estimated at 22-32 pairs, entirely in conservation areas (savanna).

(email: derek@imul.com)

PORTUGAL, S.J., MURN, C.P. \& MARTIN, G.R. (2017). White-headed Vulture Trigonoceps occipitalis shows visual field characteristics of hunting raptors. Ibis 159: 463-466.

Maximum binocular field width, measured in two birds, was $30^{\circ}$, wider than in two species of Gyps $\left(20^{\circ}\right)$. Similar difference was seen in the binocular vertical height.

(email: steve.portugal@rhul.ac.uk) 
RIDDELL, I.C. (2017). An Egyptian Vulture at Mana Pools. Honeyguide 63: 71.

A fresh juvenile was seen close to Kanga camp in October 2016. A juvenile had also been seen a year before, over the river in Zambia.

(email: gemsaf@mango.zw)

ROYTE, E. (2016). Bloody good. National Geographic 229(1): 70-97.

Based around the Masai Mara and the Serengeti, this story is about the vultures feeding, and on their being poisoned by Furadan. Interviews Darcy Ogada, Munir Virani and Simon Thomsett. Includes a pull-out describing the world's 23 species. Many lovely photos from Charlie Hamilton James.

SANTANGEli, A., GIRARDELlO, M., BUECHLEY, E., BOTHA, A., DI MININ, E. \& MOILANEN, A. (2019). Priority areas for conservation of Old World vultures. Conservation Biology.

Distributions of all 15 species in Europe, Asia and Africa, and their threats, were studied. Important areas were southern and eastern African, south Asia, and the Iberian peninsula. $80 \%$ of these areas were unprotected. The number of priority areas was positively correlated with cost of rabies protection.

(email: andrea.santangeli@helsinki.fi)

SCHABO, D.G., HEUNER, S., NEETHLING, M.V., RÖSNER, S., UYS, R. \& FARWIG, N. (2017). Long-term data indicates that supplementary food enhances the number of breeding pairs in a Cape Vulture Gyps coprotheres colony. Bird Conservation International 27: 140-152.

The study was done at Mzimkhulu colony in KwaZulu-Natal, in the years 2001 to 2012. Vultures were counted and carcasses at the nearby restaurant were estimated for weight. Number of breeding pairs was correlated to amount of food at the restaurant early in the season.

(email: dana.berens@staff.uni-marburg.de)

SMALLEY, M. (2016). Hooded Vultures Necrosyrtes monachus in Fajara, coastal area of The

Gambia, between 1978 and 1981. Malimbus 38: 10-14.

Counts of vultures were made on 79 evening walks on the 24 ha campus of the Medical Research Council, and on hundreds of observation days. Vultures were sighted on $98 \%$ of days, and an average of two birds per walk, with 34 at a termite emergence.

(email: michaelsorama@gmail.com)

STOCKIL, C. \& WALTON, S. (2016). A Palm-nut Vulture in the Gonarezhou National Park. Honeyguide 62: 28.

Three sightings of an adult, Sept./Oct. 2015, all near to the Save-Runde junction (bordering Mozambique).

(email: clive@ chilogorge.com) 
TAYLOR, M. R. \& PEACOCK, F. (2018). The state of South Africa's birds. BirdLife South Africa, Johannesburg. 80pp.

In colour, with many photographs and charts, and a couple of maps. Vultures feature on five pages, with various conservation actions listed, including VulPro's rehabilitation efforts, and the Multispecies Action Plan under the CMS Convention.

(email: info@birdlife.org.za)

VENKITACHALAM, R. \& SENTHILNATHAN, S. (2016). Status and population of vultures in Moyar Valley, southern India. Journal of Threatened Taxa 8: 8358-8364.

Four species considered, but no results for the Egyptian Vulture. Indian Griffon (4 pairs) and Whiterumped Vulture (36 pairs) nest in the area, and Red-headed Vulture was also seen. Largest flock of bengalensis was 79 birds, and eight for the griffon (here called Indian Vulture). Monitoring efforts are recommended.

(email: poojithvenkat@gmail.com)

VENKITACHALAM, R. \& SENTHILNATHAN, S. (2018). White-rumped Vulture: new features and nest tree characteristics of Gyps bengalensis ... in Moyar Valley of Tamil Nadu, India. (Bird-oSoar \#20). Zoo's Print 33(8): 19-25.

In 2012 and 2014, 31 nests were located and described. Generally, nest trees were larger than randomly selected non-nest trees.

(email: poojithvenkat@gmail.com)

WANI, H.M., BHAT, B.A., FAZILI, M.F., SHANSAZ, U.H., ul HAQ, I. \& BHAT, R.A. (2018). Status of vultures in India: a review. International Journal of Advanced Scientific Research and Management 3: 181-187.

General review, but with some mistakes. There are more threats than just diclofenac, and nine recommendations are made, including "using nets below the nests to minimise egg destruction"!

(Dept. Zoology, University of Kashmir, Srinagar 190006, India)

WHYTE, I.J. (2018). Vultures high flying sleuths. Kruger Magazine 5: 46-55.

A general article with many good photos of all five common species in the region. Mentions the months-long stay of a juvenile Egyptian Vulture in the park.

WILLIAMS, V.L., CUNNINGHAM, A.B., KEMP, A.C. \& BRUYNS, R.K. (2014). Risks to birds traded for African traditional medicine: a quantitative assessment. PLoS ONE 9(8): e105397.

The Hooded Vulture was the $3^{\text {rd }}$ most frequently recorded species in various of 25 African countries. Among 18 species of conservation concern were six species of vulture, headed by the Cape Griffon. (email: vivwill@ netdial.co.za) 
WOLTER, K., NESER, W., HIRSCHAUER, M.T. \& CAMIŇA, A. (2016). Cape Vulture Gyps coprotheres breeding status in southern Africa: monitoring results from 2010-2014. Ostrich 87: 119123.

Seven colonies from the old Transvaal and one in southern Botswana were counted up to three times per year. In total, 1776 pairs were seen in 2014, a slight increase over previous years. Breeding success varied between $35 \%$ and $96 \%$. The authors call for a transnational coordinated breeding census.

(email: kerri.wolter@gmail.com)

$* * * * * *$ 